\title{
PPP2R3B wt Allele
}

National Cancer Institute

\section{Source}

National Cancer Institute. PPP2R3B wt Allele. NCI Thesaurus. Code C52098.

Human PPP2R3B wild-type allele is located the vicinity of either Xp22.33 or Yp11.3 and is approximately $53 \mathrm{~kb}$ in length. This allele, which encodes serine/threonine-protein phosphatase $2 \mathrm{~A}$ regulatory subunit $\mathrm{B}$ " subunit beta protein, plays a role in the modulation of cellular proliferation. 